\title{
ARTICLES
}

Submitted 02.24.2014. Approved 05.13.2014

Evaluated by double blind review process. Scientific Editor: Percy Marquina Feldman

DOI: http://dx.doi.org/10.1590/So034-759020160102

\section{RELATION BETWEEN BACKGROUND VARIABLES, VALUES AND CORPORATE SOCIAL RESPONSIBILITY}

\author{
Relação entre variáveis de base, valores e responsabilidade social corporativa \\ Relación entre las variables contextuales, los valores y la responsabilidad \\ social corporativa
}

\begin{abstract}
Consumer perception of corporate social responsibility (CSR) can be directly influenced by individual value structures. This research aims to provide new knowledge regarding the relationship between basic human values and the public's perception of CSR. It focuses on the values of higher education students and their views regarding a particular corporate social initiative. The study reveals that social, educational, and economic circumstances influence human values. Those values in turn influence why different students perceive CSR differently. These findings are relevant to companies as they provide a more detailed understanding of why certain consumer groups perceive certain CSR initiatives the way that they do. They also suggest that universities should increase their awareness of the importance of integrating human values and CSR in the curricula of future business managers and social leaders.
\end{abstract}

KEYWORDS | Human values, Schwartz's Theory, corporate social responsibility, perception, higher education.

\section{RESUMO}

A percepção que o consumidor tem da responsabilidade social corporativa (RSC) pode ser diretamente influenciada por estruturas de valores individuais. O presente estudo tem como objetivo proporcionar novos conhecimentos sobre a relação entre valores humanos básicos e a percepção que o público tem da RSC. Ele concentra-se nos valores de alunos universitários e seus pontos de vista sobre uma determinada iniciativa social corporativa. $O$ estudo revela que circunstâncias sociais, educacionais $e$ econômicas influenciam os valores humanos. Esses valores, por sua vez, influenciam o motivo de diferentes alunos perceberem a RSC de formas diferentes. Os resultados são relevantes para as empresas, na medida em que permitem uma compreensão mais detalhada da razão pela qual certos grupos de consumidores percebem de determinada forma certas iniciativas de RSC. Também sugerem que as universidades sejam mais conscientes da importância da integração dos valores humanos e da RSC nos currículos de futuros gestores de negócios e líderes sociais.

PALAVRAS-CHAVE I Valores humanos, Teoria de Schwartz, responsabilidade social corporativa, percepção, ensino superior.

\section{MARÍA DEL CARMEN DÍAZ \\ FERNÁNDEZ}

cardiaz@us.es

Professor at Universidad de Sevilla, Facultad de Turismo y Finanzas -

Sevilla, Spain

\section{VALÉRIA RUEDA ELIAS SPERS}

vrueda@unimep.br

Professor at Universidade Metodista de Piracicaba, Faculdade de Gestão e Negócios - Piracicaba - SP, Brazil

\section{MARCELO DA SILVA LEITE}

masleite@unimep.br

Professor at Universidade Metodista de Piracicaba, Faculdade de Ciências Humanas - Piracicaba - SP, Brazil

\section{RESUMEN}

La percepción del consumidor respecto de la responsabilidad social corporativa (CSR por su sigla en inglés) se puede ver directamente influenciada por las estructuras de valores de la persona. Esta investigación se propone brindar nuevos conocimientos acerca de la relación entre los valores humanos básicos y la percepción pública de la CSR. El mismo se centra en los valores de estudiantes pertenecientes al nivel superior de educación y sus visiones en relación a una iniciativa social corporativa en particular. El estudio revela que las circunstancias sociales, educativas y económicas ejercen influencia sobre los valores humanos. A su vez estos valores influyen en los motivos por los cuales diferentes estudiantes perciben de manera diferente a la CSR. Estos descubrimientos resultan relevantes para las empresas, ya que brindan una comprensión más detallada de los motivos por los que determinados grupos de consumidores perciben determinadas iniciativas de CSR de una manera particular. Sugieren además que las universidades deben incrementar su conciencia de la importancia de la integración de los valores humanos y la CSR a los planes de estudio de los futuros gerentes comerciales y líderes sociales.

PALABRAS CLAVE / Valores humanos, Teoría de Schwartz, Responsabilidad social corporativa, percepción, educación superior. 


\section{INTRODUCTION}

Although research on the relationship between social demographics and value structures can be found in the literature (Wang \& Juslin, 2012), few studies have empirically analyzed the influence of the framework of human values on the perception of corporate social responsibility (CSR) in the context of higher education (Rama, Ravenscroft, Wolcott, \& Zlotkowski, 2000; Sobczak, Debucquet, \& Havard, 2006; Weber, Weber, Sleeper, \& Schneider, 2004; Weber \& Glyptis, 2000; Wong, Long, \& Elankumaran, 2010). Despite the scarcity of studies, consumer perception of CSR can be an important determinant of the success of CSR practices in any organization. With regard to that importance, Buil, Melero, and Montaner (2012) noted that firms should collaborate with causes linked not only to their main activity but also in tasks consumers feel involved with, particularly altruism-motivated ones. Unfortunately, as PerezRuiz and Rodriguez-Del Bosque (2012) manifest, evidence on this issue point to customer perceptions according to which CSR activities are more directly linked to the firm's pursuit of its own benefit than to philanthropic and ethical considerations.

Despite these previous arguments, doubts still exists both in academe and in managerial practice as to whether CSR can influence consumer-related issues such as perceptions or purchasing behavior (Bigne-Alcaniz \& Curras-Perez, 2008). In order to address this question, the present study analyses and determines what can actually influence perceptions of a particular CSR activity, and how different perceptions are influenced by different experiences and related values, rather than by the activity itself and its success or failure. Therefore, this paper will show that this relationship is scarcely taken into account, based on a review of the existing literature.

To this end, the present study, which is based on a sample of 1,060 Spanish higher education students, aims to analyze the following issues: i) the influence of background variables on human values; ii) and the extent to which perceptions of a social initiative are influenced by these students' values structure. The main purpose of this study is to reinforce CSR's social dimensions according to the Triple Bottom Line, since this perspective may be considered strategic not only for company success but also for stakeholders (Arratia Figueroa, 2008). A comprehensive study exploring the relationship between CSR perception and human values in the context of higher education involves an accurate understanding of how CSR curricula can be designed. In this respect, as Frazer and Kornhauser (1988) noted, ethics and social responsibility play an important, transcendental role in educational institutions, society, and firms.
The structure of this paper is as follows. Firstly, we provide a review of the concept of human values, including Schwartz's theory on the subject. The paper then explores the literature on the role of values as drivers of the public perception of CSR. After this, it describes the model formulated to test the hypotheses we present. The research method, sampling details, and statistical tools are then described. Finally, we discuss our findings and assess their significance. We conclude by reflecting on the study's limitations and suggest a research agenda to address them.

\section{HUMAN VALUES AND SCHWARTZ'S VALUE THEORY}

A universal definition regarding human values is not found in the literature (Lan, Gowing, McManhon, Rieger, \& King, 2008). However, over the last decade, Schwartz and his colleagues' definition has been broadly adopted (Siltaoja, 2006). Schwartz and Bardi (2001) have defined values as desirable, transsituational goals that vary in importance, serving as guiding principles in people's lives. Individual motivations are crucial in distinguishing among human values. Furthermore, Schwartz (1994) delimited these motivational goals and established that values are answers to the following constrictions: personal relations, social relations, and survival needs.

With regard to this premise, Schwartz $(1992,1994)$ grouped the 56 original values into ten value categories, which were further clustered into four higher order value orientations: 1) Self-transcendence (universalism and benevolence values), 2) Self-enhancement (power and achievement), 3) Openness to change (self-direction, hedonism, and stimulation), and 4) Conservation (tradition, conformity, and security). This taxonomy of values, which is called the Schwartz's value system (SVS) (Perrinjaquet, Furrer, Usunier, Cestre, \& Valette-Florence, 2007), was commonly represented by Schwartz and his colleagues as a two dimensional, circular structure representing a continuum of values (Figure 1). The position of human values in Figure 1 shows values' degree of proximity or disconformity between them (Schwartz, 1992, 1994). Therefore, the circle has two opposite dimensions: on one hand, the dimensions of self-enhancement (power, achievement) and self-transcendence (benevolence, universalism); and, on the other hand, the dimensions of conservation (security, conformity, tradition) and openness to change (self-direction, stimulation). Hedonism can be placed either in the self-enhancement dimension or the openness to change dimension. 
Figure 1. Theoretical model of relations among ten motivational types of values

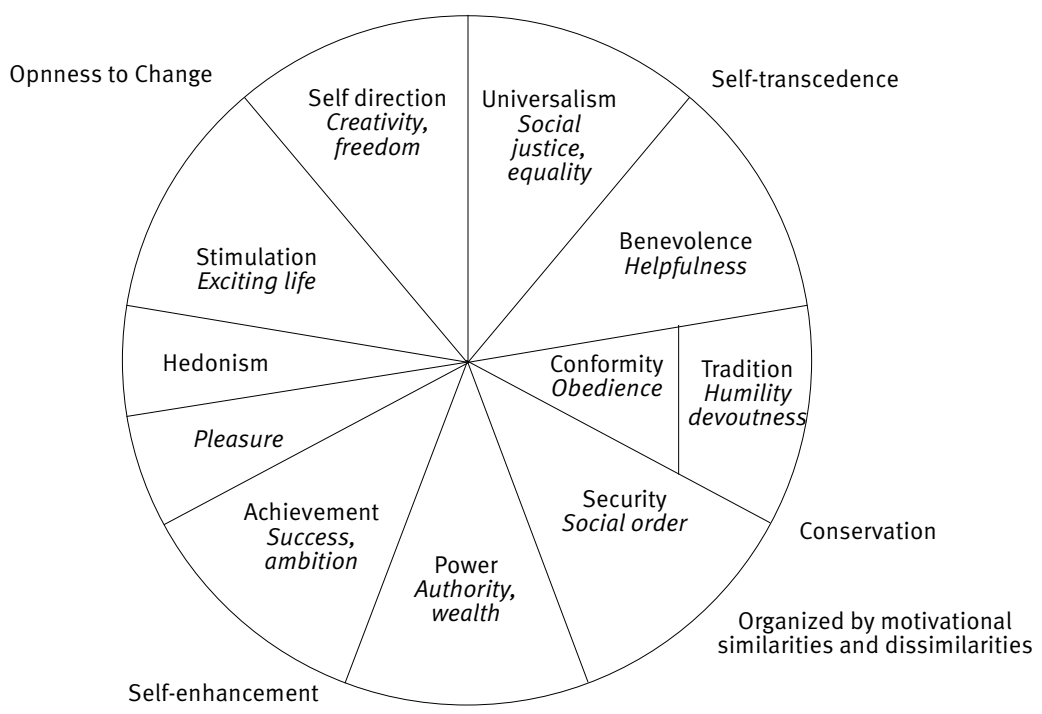

Note. Adapted from “Advances in experimental social psychology” by S. H. Schwartz, S. H., 1992. San Diego, CA: Academic Press.

The human value framework above (SVS) has been strongly supported with samples from different cultural contexts (Schwartz \& Sagiv, 1995; Schwartz, Melech, Lehmann, Burgess, \& Harris 2001) and has been tested and found to have predictive validity in several diverse academic areas such as psychology (Wilson, 2005), marketing (Steenkamp, Hofstede, \& Wedel, 1999), and international business (Egri \& Ralston, 2004). However, this model has also been criticized for the psychometric scale and collinearity issues observed between the values (Olver \& Mooradian, 2003; Thøgersen \& Ölander, 2002). Other scholars have argued that the empirical findings using the human values framework fail to provide convincing arguments for Schwartz's SVS structure (Perrinjaquet et al., 2007).

Despite these disagreements, the model continues to be used. Koivula (2008) highlights that Schwartz's value system is well adjusted to the basic human condition. However, the present study holds that value structures may change over time in response to changes in social patterns, technology, and economic and political events.

\section{CORPORATE SOCIAL RESPONSIBILITY AND THE TRIPLE BOTTOM LINE}

The literature lacks a consensus on the notion of CSR (Wang \& Juslin, 2012). Wang and Juslin (2012) conducted a revision of CSR concepts in the literature, and the present paper adopts a definition based on the 'Triple Bottom Line' term, relating the concept of CSR with three dimensions or perspectives: 1) economic responsibility (firm performance); 2) environmental responsibility (environment sustainability); and 3) social responsibility (individuals' well-being) (Norman \& MacDonald, 2004).

The importance of CSR's social dimension motivated the present study, which focuses on the connection between Schwartz' theory of values and the perceptions of a particular social initiative conducted by a particular company.

To this end, we studied the social initiative (CSR's social dimension) mainly as it is perceived by higher education students acting as consumers, and used four questions indicating: a) Acceptance, which describes how much an individual likes the initiative; b) Perceived value, representing how good the initiative is in the individual's perception; c) Support, describing how much the individual supports the initiative; and d) Perceived usefulness, i.e., how useful the initiative is in the individual's perception.

Concerns related to the concept of CSR grow as different dimensions are added to it, leading to a lack of consensus about findings; such concerns occupy an important place in the literature (Baden, Harwood, \& Woodward, 2009; Fernando, 2010; Fernando \& Sim, 2011; Ibrahim et al., 2006; Perrinjaquet et al., 2007; Pomering \& Johnson, 2009). Business leaders have also manifested different views about the concept of CSR (Sprinkle \& Mainess, 2010). Furthermore, in this specific entrepreneurial context, i.e., one of economic constrains, implementing social responsibility actions is not an easy task (Fernando \& Almeida, 2012). However, CSR accomplishment by firms is increasing, with a view to consumer acceptance, consumer loyalty, and, therefore, firm performance 
(Gladwell, 2000). More than just a fad (Bowd, Bowd, \& Harris, 2006), CSR activities have developed to become programs that companies must undertake (Macalister, 2008; Willman, 2008).

Nevertheless, despite all concerns with social responsible activities' implementation, few studies to date have analyzed in a combined way CSR perception and the value structure of the individuals CSR activities aim to address (Harwood, Humby, \& Harwood, 2011). This research gap is even bigger when it comes to higher education (Weber et al., 2004), particularly in business studies (Arlow, 1991). Although a few studies have focused on patterns of managers and business students in relation to CSR (Longenecker, McKinney, \& Moore, 1989; Stevens, 1984), to date there is insufficient research and no conclusive knowledge or findings on how human values are constructed, how those values influence perceptions, and how perceptions may vary particularly regarding different CSR activities.

\section{VALUES VERSUS CSR: MODEL AND HYPOTHESIS}

In sociology, values are considered as drivers that can influence human action (Wang \& Juslin, 2012). Values are clearly manifested not only by individuals but also by institutions and society (Hofstede, 1980). Likewise, values display an important role on each level of a firm, guiding the setting of goals, resource allocation, and the designing of strategies (Rokeach, 1979). According to Argandoña (2003), values are part of firms' competences, shaping their long-term success.

The relationship among values, attitudes, and behavior is not a straightforward one (Barth, 1993) and the sense and intensity of this relationship is not clearly established. While some authors show a weak relationship (Kristiansen \& Hotte, 1996), others manifest strong situational force acting between values and behavior (Feather, 1996).

Schwartz (1996) described the process that might connect people's priorities in terms of values with their attitudes and behavior. Values influence the perception and interpretation of different situations, and, therefore, they can show how social science students acting as consumers in a specific cultural context can perceive a social initiative launched by a company.

A consensus seems to exist among the theories found in the literature, according to which, human values can influence human patterns (Wang \& Juslin, 2012). In addition, people from different cultural contexts show different value structures (Schwartz, 1994, 1999), which can influence their own perception of reality and guide their attitudes (Siltaoja, 2006). Thus, the evaluation of CSR actions is determined by human values and cultural-societal norms in combination with a number of other considerations that can influence how individuals evaluate such activities (Hemingway \& MacLagan, 2004).

According to the findings above, this paper will first explore the extent to which Schwartz's value theory is applicable to a sample of Spanish students from different social science courses in higher education, including tourism, finances, labor relations, psychology, educational science, economics, and business management. Secondly, the degree of influence between these students' personal values and their CSR perception is analyzed. The findings are more accurate than those obtained by other researchers who focused on a single higher education course (Rama et al., 2000; Sobczak et al., 2006; Wang \& Juslin, 2011, 2012), more specifically bachelor of accounting, with findings extended to the whole area of business management. That procedure has been strongly criticized. Therefore, Weber et al. (2004) concluded that very little research on students presents distinctions among study areas, which presupposes homogeneity in the student population. Similar arguments can be found in Coate and Frey's (2000) work, according to which research on students from bachelor of business management courses are scarce, making it inappropriate to draw conclusions for the population of a whole university. Consequently, additional studies are required.

To address what was discussed above, we formulated the hypotheses below according to Schwartz's (1992,1994) theoretical framework, included in the proposed model (Figure 2):

$\mathrm{H}_{1}$ : Differences in human values regarding gender can be found.

$\mathrm{H}_{2}$ : Human values depend on the educational context.

$\mathrm{H}_{3}$ : Human values are a function of family economic status.

$\mathrm{H}_{4}$ : Self-transcendence values are more developed in students who obtain a public grant or work to fund their studies. Family-supported students are more concerned with self-enhancement values.

$\mathrm{H}_{5}$ : Differences can be found in the average perceptions of the social dimensions (acceptance, value, support, and usefulness) of CSR in the target group.

$\mathrm{H}_{6}$ : Positive CSR perception (acceptance, value, support, and usefulness) is positively correlated to the higherorder value of self-transcendence (benevolence and universalism).

$\mathrm{H}_{7}$ : Positive CSR perception (acceptance, value, support, and usefulness) is positively correlated to the higher-order value of conservation (security, conformity and tradition) 
Figure 2. The study's theoretical model

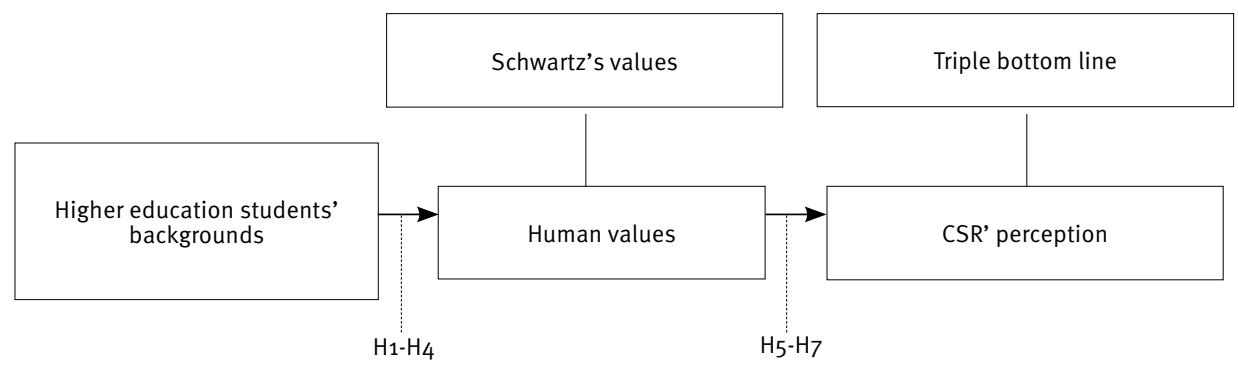

\section{METHOD}

Participants in this study were Spanish social sciences students. These students were contacted with help from the registration office over the period the study was conducted. They completed the questionnaire and received instructions to fill out the survey. Initially, 1,200 students took part in the study. Respondents who did not answer all questions or who provided the same answer for all values items in the questionnaire, indicating deliberate misrepresentation (140 students), were excluded from the analysis (Schwartz, 2005a, 2006).

The descriptive analysis of the sample (Table 1 ) reveals a balance between male and female students, with the majority coming from families of middle economic status and high or middle education level. Only a third of the students relied on public grants to support their studies.

Table 1. Descriptive statistics for background variables

\begin{tabular}{l|c|c}
\hline \multirow{2}{*}{ Gender } & Categories & $\begin{array}{c}\text { Percentage } \\
\text { N=1060 }\end{array}$ \\
\hline \multirow{3}{*}{ Secondary school } & Male & 50.4 \\
\cline { 2 - 3 } & Female & 40.6 \\
\cline { 2 - 3 } & Public & 73 \\
\hline \multirow{3}{*}{$\begin{array}{l}\text { Ways to fund } \\
\text { studies }\end{array}$} & Private & 24 \\
\cline { 2 - 3 } & Gemi-private & 2.3 \\
\cline { 2 - 3 } Family's economic & Family & 12 \\
\cline { 2 - 3 } status & High & 52.5 \\
\cline { 2 - 3 } & Medium & 7.3 \\
\hline \multirow{2}{*}{$\begin{array}{l}\text { Family's } \\
\text { educational level }\end{array}$} & Low & 88 \\
\cline { 2 - 3 } & High & 12 \\
\cline { 2 - 3 } & Medium & 53.6 \\
\cline { 2 - 3 } & Low & 64.1 \\
\hline \multirow{2}{*}{ Age } & $18-20$ & 9.5 \\
\hline
\end{tabular}

The questionnaire was designed with three welldifferentiated types of questions: 1) Questions related to value priorities; 2) Questions related to attitudes towards a social initiative; 3) Background variables.

In order to measure individuals' values, the questionnaire included 21 value items used in the European Social Survey (EES). Most of these EES items are from the portrait values questionnaire (PVQ) scale, and we added a few other items to provide information on Schwartz's ten values. The PVQ includes short verbal questions to reveal respondents' goals, aspirations, and wishes reflecting their own human values.

Participants completed the 21 value items on a 6-point Likert scale where $1=$ "Not like me at all", and $6=$ "Very much like me" (6). The items were combined in ten indexes. Universalism was measured by three items, while the others were measured by two items each. The items were designed to cover different dimensions of a basic human value (Schwartz et al., 2001). The individual scores for the ten values were centered by subtracting the individual's 21 items average, and the main descriptive statistics are shown in Table 2 (Schwartz, 2005a).

A brief description of a corporate social initiative was included in the questionnaire: "Company A starts a three-year social initiative to fight child undernourishment. The program consists of providing assistance to primary school cafeterias in town $B$. In addition to financial support, the program will include the supplying of food products and voluntary work by the firm's employees; volunteers will give advice on the menu and help in the cafeterias' renovation works. The total amount donated to the cafeterias will be approximately \$30,000.

In brief, the implemented program will have the following features:

a. Support will be provided for a period of three years;

b. The subject matter is child and youth undernourishment;

c. Support will be both financial and in kind, as well as in the form of voluntary work. 
Table 2. Descriptive statistics for human values

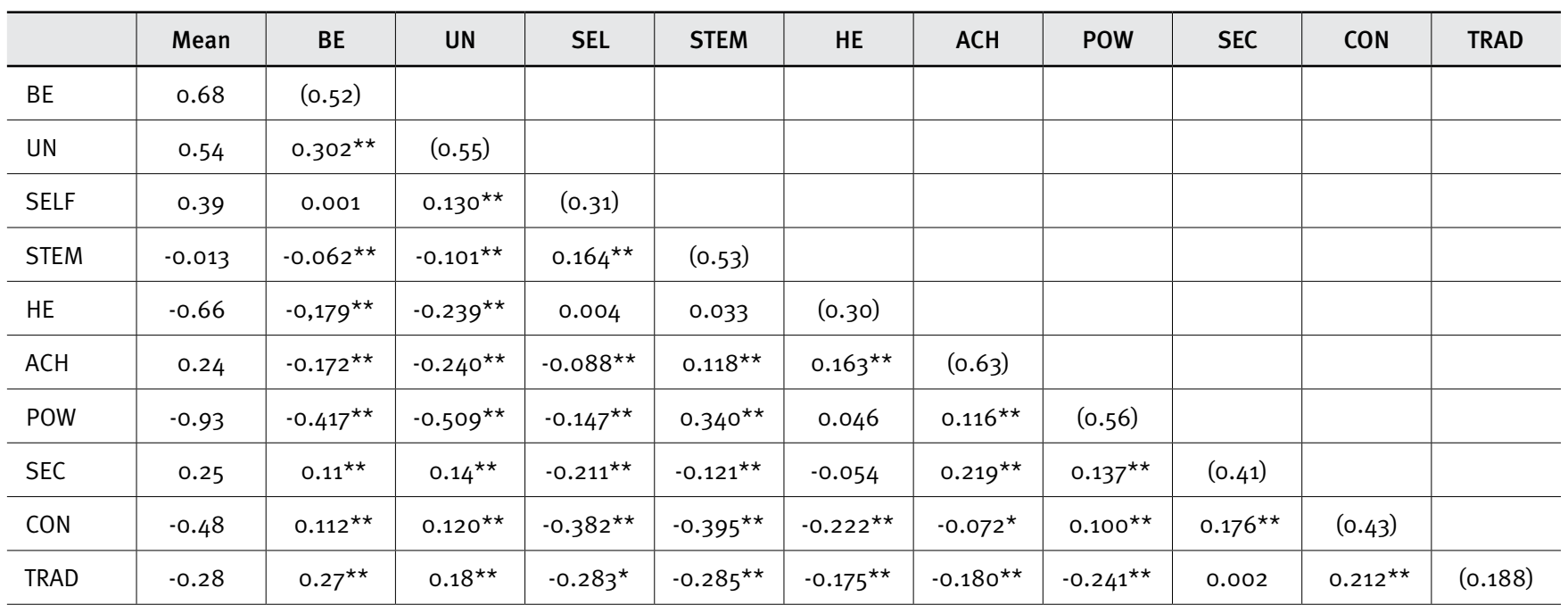

Note. $\mathrm{SD}=$ Standard deviation; $\mathrm{BE}=$ Benevolence; $\mathrm{UN}=$ Universalism; SELF = Self-direction; STEM = Stimulation; HE = Hedonism; $\mathrm{ACH}=\mathrm{Achievement;} \mathrm{POW}=$ Power; SEC $=$ Security; $\mathrm{CON}=$ Confidence; TRAD $=$ Tradition

Correlations ** are significant at 0.01. *significant ato.05 (correlation values lower than 0.06 )

Moreover, on a 1 to 7 Likert scale, where $1=$ 'I don't like it at all', and $7=$ 'l like it', each student interviewed answered four questions aimed at quantifying the intensity (positive or negative) of their opinions/perceptions of the social initiative in four dimensions: a) How much do you like this initiative?; b) How good is the initiative in your opinion?; c) How much do you support the initiative?; d) How useful is the initiative? Question a) shows the degree of acceptance of the social initiative; question b) evidences its perceived ethic value; question c) shows the degree of support for the initiative; and question d) shows its perceived utility.

The following background variables supposed to influence value priorities were included in the questionnaire (Table 1): age (1: $18-20 ; 2: 21-24 ; 3: 25$ or older), gender (1: male; 2 : female), secondary education (1: public; 2 : private; 3 : semi-private), interviewee's education funding (1: grants; 2 : own work; 3 : family), economic level of interviewee's immediate environment (1: high economic status; 2 : medium economic status; 3: low economic status), level of education of interviewee's immediate environment (1: high education level; 2: medium education level; 3: low education level).

\section{Data analysis}

The ten value priorities were calculated as the mean of the items listed in each value. Due to individual differences in the interpretation of the Likert scale (Schwartz \& Bardi, 1997; Smith, 2004), corrections in the responses were necessary to properly measure the human values. What actually matters is the value's relative importance against its absolute importance. To obtain the relative importance for the ten priority values, the following correction was applied: the individual scores of the ten values were centered by subtracting the 21 items' average (Schwartz, 2005b, 2006).

To explore how background variables relate to value priorities, an independent sample t-test and ANOVA and Bonferroni post hoc tests were conducted.

A Friedman and post hoc Wilcoxon test was applied to detect differences on perceptions among the four CSR social dimensions. To examine where the differences actually occur, we conducted the Wilcoxon signed-rank test for comparison between the combinations, Da to Db, Da to Dc, Da to Dd, Db to Dc, and Dc to Dd. Respondents scored higher for certain dimensions compared to the others, which appears to indicate the existence of several factors, including human values and background variables, influencing how the students perceive the four CSR social dimensions.

The independent effect of the ten personal values on the perception of social initiatives was studied using linear regression analysis. According to Schwartz's value theory: "all the values are dynamically related" (Schwartz, 1992, p. 13). Due to co-linearity among value priorities, some of these predictors were excluded in the linear regression. The predictor variables included in the regression analysis were the values with statistical influence on the perception of the social initiative.

In order to select background variables as control variables in the regression analysis, we used an independent sample t-test and ANOVA analysis to determine whether any significant differences existed in the students' perceptions of the social initiative. The gender variable was used as control in the whole 
regression analysis, since significant differences in students' behavior were observed between male and female subjects in the four aspects of the social initiative: acceptance, perceived value, support, and perceived usefulness. No clear differences were observed for the other background variables on the four social initiative dimensions.

\section{RESULTS AND DISCUSSION}

An independent sample t-test showed statistically significant differences between men and women in benevolence $(t=5.08$, $\mathrm{p}<=0.001)$, universalism $(\mathrm{t}=4.62, \mathrm{p}<0.001)$, stimulation $(\mathrm{t}$ $=-2.777, p<0.01)$, hedonism $(t=-5.662, p<0.001)$, power $(t=$ -6.737, $p<0.001)$, security $(t=4.158, p<0.001)$, conformity $(t=$ $2.992, p<0.01)$, and tradition $(t=2.234, p<0.05)$. No significant gender-related differences were found for self-direction and achievement. Hypothesis 1 was partially confirmed. The results reveal that women valued self-transcendence (benevolence and universalism) and conservation (security, tradition, and conformity) more than men, while men valued power and hedonism more than women. Value differences between males and females could be attributed not only to genetic reasons but also to family environment. In a traditional family culture such as the Spanish, women are expected to develop values related to caring and supporting people in need, while men are allowed to behave in a more aggressive way (Gisber, 2007). This finding corroborates other conclusions regarding gender that have been evidenced in the literature (Betz et al., 1989; Ruegger \& King, 1992).

Diverse educational environment levels reveal differences in power $(F=3.60, p=0.05)$, tradition $(F=3.30, p=0.05)$, and stimulation $(F=3.21, p<0.01)$. Students from environments of highest education level valued tradition and stimulation more those from environments of lowest education level. Hypothesis 2 was confirmed. The importance of openness to change values such as stimulation increases as the environment education level rises, although this correlation was not observed for selfdirection. Students from environments of medium education level gave more importance to power, since they were attending business courses - an integral part of higher education in social sciences - where students are trained in the managerial aspects of running a company, a bank, or other private organizations that emphasize self-enhancement values. Surprisingly, students from environments of high and medium education level valued tradition more than those from environments of low educational level, the opposite of what was expected. However, most of these students come from families who own a family business, and they wish to maintain the customs or ideas of their social environment. In fact, the southernmost region of Spain is characterized by small and medium-sized businesses, which account for $80 \%$ of total employment in the region (Gil-Pechuan, Expósito-Langa, \& Tomas-Miquel, 2013; Ruivo, Oliveira, \& Neto, 2012).

The economic level of students' original environment showed statistically significant differences for benevolence $(F=$ $5.78, p<0.01)$, universalism $(F=6.096, p<0.01)$, and power $(F=$ 12.43, $p<0.01$ ). High economic level students valued benevolence and universalism less than medium and low level ones. High economic level students valued power more than medium and lowlevel ones. Hypothesis 3 was confirmed, since self-transcendence values (universalism and benevolence) were more important for students from families of low or medium economic status. These students are more aware of the importance of understanding, appreciation, tolerance, and protection for the welfare of people and nature. As expected, students from environments of high economic status valued power more than the other groups due to their desire for social status, prestige, and control over people and resources.

Finally, different ways of funding higher education studies showed statistically significant differences for benevolence $(F=3.12, p=0.01)$, universalism $(F=12.76, p<$ $0.001)$, achievement $(F=3.12, p<0.05)$, and power $(F=6.40, p$ < 0.001 ). Students supported by families valued universalism less than those receiving grants or working to pay for their studies; family-supported students also valued benevolence less than self-supported ones. Achievement and power were positively related with family-supported students. Hypothesis 4 was confirmed, since students receiving public grants or working to pay for their studies were more concerned with selftranscendence values. They valued more the external support (grant, jobs) to continue studies. Students fully supported by their families paid more attention to self-enhancement values (achievement, power), since they were not exposed to the same pressure as the individuals relying on other funding sources. In fact, the need for a job or a public grant to continue studies developed more ethical values in the latter than in familysupported students, who were not concerned about the funds to continue studies.

To evaluate higher education students' perception of CSR, particularly concerning the above described initiative to fight child malnutrition, four questions were made about the initiative's degree of 'acceptance' (Da), 'perceived value' (Db), degree of 'support' (Dc), and perceived 'usefulness' (Dd). The four questions - 'acceptance', 'value', 'support', and 'usefulness' - were considered as endogenous variables to be explained by human values as independent variables. 
The nonparametric Friedman test $\left(\chi^{2}=88.32, p<0.001\right)$ revealed differences in the degree of perceptions for the four dimensions of the initiative. In sum, students gave 'acceptance' the highest score, and the lowest to 'perceived usefulness'. The result showed that, despite these students' awareness of the relevance of the CSR initiative measured by the four items (i.e., acceptance, support, usefulness and value), they displayed skepticism about the final benefit of a short-term initiative (a three-year initiative, in our survey) to children in a developing country. Most students were skeptical about the initiative's altruistic character, as they considered that companies embrace CSR initiatives in order to improve economic performance or their own image, thus influencing consumer purchases.

Linear regression analysis for the four social dimensions (Da-Dd) were conducted to test whether human values and gender could influence how CSR actions are perceived (Table 3). The "degree of acceptance" (Da) towards a corporate social initiative according to values and gender produced an overall significant solution $(F=14.86, p<0.001)$ with an $R$-squared $=0.102$. Although no significant coefficients were obtained for stimulation or achievement, both values were significantly and positively correlated with the acceptance of the initiative. Regression analysis revealed that the best predictors for 'acceptance' were benevolence, universalism, security, conformity, and gender. These values positively influenced the degree of acceptance of the social initiative. Furthermore, women liked the social initiative more than men did.

\section{Table 3. Regression analysis predicting perception of CSR ( $\mathrm{N}=1,060$ respondents)}

\begin{tabular}{l|l|l|l|l}
\hline & $\mathrm{Da}$ & $\mathrm{Db}$ & $\mathrm{Dc}$ & $\mathrm{Dd}$ \\
\hline $\mathrm{BE}$ & $0.08^{\star \star}$ & $0.07^{\star \star}$ & $0.09^{\star \star \star}$ & 0.02 \\
\hline $\mathrm{UN}$ & $5.21^{\star \star \star}$ & $0.14^{\star \star \star}$ & $0.16^{\star \star \star}$ & $0.12^{\star \star \star}$ \\
\hline TRAD & -0.02 & 0.01 & -0.02 & 0.04 \\
\hline $\mathrm{SEC}$ & $0.07^{\star \star}$ & $0.10^{\star \star \star}$ & & $0.08^{\star \star}$ \\
\hline $\mathrm{CON}$ & $0.09^{\star \star \star}$ & $0.08^{\star \star}$ & $1.12^{\star \star \star}$ & $0.08^{\star \star}$ \\
\hline ACH & 0.01 & 0.03 & & $0.07^{\star \star}$ \\
\hline STEAM & 0.36 & & 0.04 & \\
\hline SELF & & & 0.003 & \\
\hline GENDER & $-0.09^{\star \star \star}$ & $-0.09^{\star \star \star}$ & $-0.062^{\star \star \star}$ & $-0.10^{\star \star \star}$ \\
\hline
\end{tabular}

Note: $\mathrm{BE}=$ Benevolence; $\mathrm{UN}=$ Universalism; SELF = Self-direction; STEM = Stimulation; $\mathrm{HE}=$ Hedonism; $\mathrm{ACH}=$ Achievement; $\mathrm{POW}=$ Power; $\mathrm{SEC}=$ Security;

$\mathrm{CON}=$ Confidence; TRAD = Tradition; $\mathrm{Da}=$ acceptance dimension; $\mathrm{Db}=$ perceived

value dimension; $\mathrm{Dc}=$ support; $\mathrm{Dd}=$ perceived usefulness dimension.

${ }^{\star} \mathrm{P}<0.05,{ }^{\star *} \mathrm{p}<0.01,{ }^{* \star *} \mathrm{P}<0.001$
The "perceived value dimension" (Db) for the social initiative was explained by a regression analysis on values and gender. The regression model produced an F-test, $\mathrm{F}=16.12$, $\mathrm{p}$ $<0.001$, and explained $9.7 \%$ of the variance of the dependent variable. Beta's coefficient for achievement and tradition was not significant, although a significant, positive correlation was observed with the perceived dimension value. The best predictors for 'perceived value' were benevolence, universalism, security, conformity, and gender. These values influenced positively the degree of acceptance of the social initiative. Furthermore, women also valued the social initiative more than male students did.

The regression analysis with an R-squared $=0.095$ predicting how much students 'support' (Dc) the initiative according to values and gender displayed an overall significant test, $F=13.096, p<0.001$. The support dimension was best predicted by benevolence, universalism, security, and gender. Students who developed these values showed stronger support to the social initiative. Once again, women were more concerned with social initiatives related to the third dimension of the social initiative.

Finally, a linear regression model was estimated to explain the fourth dimension, i.e., 'perceived usefulness', through values and gender variables. The linear regression had an $R$-squared $=0.092$ and an overall significant test, $F=13.679, p$ $<0.001$. Significant, positive beta coefficients were obtained for universalism, achievement, security, and conformity, influencing positively the perceived usefulness dimension. Gender was also a statistically significant predictor.

\section{CONCLUSIONS}

Corporate social responsibility has gained increasing recognition as a new concept to be added to company performance. Global companies are far more aware of the importance of developing strategies, actions, and a reporting framework for corporate social responsibility mainly regarding environmental, economic, and social responsibilities. Since most students in social sciences will become executives or professionals who participate in companies' decision-making processes, it is worth noting how the values of today's students can influence perceptions of a social initiative run by a firm.

Schwarz's theory indicates that people develop certain values more than others and it is logical to expect these differences to influence individual perception of corporate social initiatives. Likewise, the present study has a double aim. Firstly, we sought to explore the influence of different background variables on the individual value structure. Most of these background variables 
have not been studied in the literature, and, therefore, this study provides a better understanding of the personal value structure Secondly, we sought to study how students' personal values can influence their perceptions of a social program dedicated to fighting child malnutrition. It is acknowledged that CSR consists of more than a concern with the ill effects of urban poverty on child malnutrition - e.g. concerns with the environment, corporate governance, etc. However, for the purpose of this article, the main goal was to focus on how the interviewed students perceived one particular CSR-related initiative of the type that is generally better accepted and valued by the general public than economic initiatives (Arratia Figueroa, 2008).

We chose higher education students as the subjects of our study based on a double criterion. These students are predicted to be the most complex and influential group of consumers within the next couple of years (Schmeltz, 2012); at the same time, they are most likely to be the future leaders and managers in their society. Their attitudes certainly can provide evidence about their future behavior.

The findings obtained from the analysis lead to a better understanding of the value structure of Spanish higher education students and the forces that shape their ethical perceptions. These results can help educators to devise business ethics/CSR education programs, and help managers to develop strategies for the success of a social initiative, since knowing how consumers perceive CSR is a key factor to make sound strategic decisions.

People adapt their value structure to their life circumstances, and, in turn, different life circumstances also affect value priorities (Yao, Cheng, \& Cheng, 2009). Our results regarding the relationship between values and gender, education, and other background variables in a Spanish higher education institution were mostly in line with previous research on this issue (Wang \& Juslin, 2012). The sample revealed, firstly, that women developed self-transcendence values more than men, while men were more concerned with self-enhancement values. Secondly, the education level of students' environments increases openness to change values and decreases conservation values. Thirdly, the economic level of individuals' upbringing environment helps shape their value priority structure. Undergraduate students from a favorable economic environment are encouraged to develop values related to openness to change (self-direction, stimulation) and self-enhancement (achievement, power).

Finally, the best defining feature of Spanish higher education is financial shortage. Despite a sustained growth in public grants was observed in the 1980's and 1990's, thus allowing disadvantaged social groups to reach higher education, in the last few years, Spain has faced an adverse situation in public education funding compared to other EU countries. Furthermore, grants per student in Spain are much lower than those in other EU countries (Calero, 2003), with a high number of students relying on family support to fund their degrees, and an increasing number working to support their studies. The awareness of the importance of funding among self-supported and grant-supported students certainly influences their value priorities. These students are expected to value self-transcendence (benevolence, universalism) more than family-supported students.

It is worth stressing that the core of the corporate social initiative in this study is focused on fighting child malnutrition. That initiative is based on the social dimension of CSR related to human rights, which is generally better accepted and valued by the general public than the economic initiatives, which the public perceives as profit-oriented. It can be argued that students manifested a higher acceptance of the social initiative while revealing their disagreement with its usefulness. Our findings highlight the awareness of the need for social initiatives combined with a skepticism about the final benefit to the poor community. This skepticism is often related to both the form and length of the social initiative, and whether it fits the main goal of the company. In fact, Pomering and Johnson (2009) suggest that three CSR variables are critical in trying to inhibit skepticism and enhance credibility: social topic information, long-term CSR commitment, and CSR impact specificity. Although the students recognized the initiative as good practice, they are reluctant to believe that a short-term social action (a three-year social initiative, in our study) can lead to some improvement in the essential human rights of a community in need.

Recent research of ethical ideologies has proven that individuals' ethical values have a significant impact on consumer decision in relation to socially responsible companies (Pelsmacker, Janssens, Sterckx, \& Mielants, 2006), and an impact on their perceptions of the importance of CSR (Axinn, Blair, Heorhiadi, \& Thach, 2004). The influence of values on the perception of the four aspects of a social initiative (i.e., acceptance, value perceived, support, perceived usefulness) has also been recognized in this study. Social science students with higher ethical values and women have displayed a positive perception of a social initiative as shown in other studies (Forsyth, 1980; Wang \& Juslin, 2012). Hence, CSR education should focus not only on providing students with a better understanding of the CSR concept but also on cultivating awareness about responsibility for the environment and society. Accordingly, these educational social agents, together with other entrepreneurial agents, have an important role to play in building a new kind of responsible consumerism, thus ensuring, among others, that both companies and consumers may benefit from a more symbiotic relationship (Smith \& Williams, 2011). 


\section{LIMITATIONS AND FUTURE RESEARCH}

The success of CSR relies not only on the legal and political regulations where social practices are implemented and developed but also on the evolution of civil society towards a better comprehension of CSR (Choi \& Gray, 2008). This social concept emerges from a business context (Dahlsrud, 2008). In this respect, this study is based on the demand side of CSR by analyzing the attitudes of young generations towards CSR and detecting those factors influencing CSR perceptions. The results obtained reflect ways to improve understanding of the principles underpinning CSR.

Further research on how personal values influence students' perception in different dimensions (economic, social and environmental dimension) would complement this study, which was focused on the social dimension related to human rights and social cooperation. The results will enable academics and managers to challenge misunderstandings about CSR principles and the skepticism observed in a large consumer segment, higher education students.

Structural equation modeling was used to detect the influence of the ten basic values on consumer behavior according to the economic, ethical, and environmental dimensions. Since being enrolled on CSR courses will affect students' attitudes towards a social initiative, future research to determine the influence of that variable on CSR perception is needed. The structural equation model will include enrollment and other interesting background variables as control variables influencing human values, and, therefore, the perception of CSR.

A study encompassing a longer period of time would provide a greater understanding about how new generations will improve their understanding of CSR and its implications for society through better designed CSR curricula, an accurate promotion by companies, and the implementation of CSR practices by universities.

\section{REFERENCES}

Arlow, P. (1991). Personal characteristics in college students' evaluations of business ethics and corporate social responsibility. Journal of Business Ethics, 10(1), 63-69. doi:10.1007/bfo0383694

Argandoña, A. (2003). Teoría de la acción y la teoría económica, La (No. D/484). IESE Business School.

Arratia Figueroa, A. (2008). Ética, solidaridad y "aprendizaje servicio" en la educación superior. Acta Bioethica, 14(1), 61-67.

Axinn, C. N., Blair, E., Heorhiadi, A., \& Thach, S. V. (2004). Comparing ethical ideologies across cultures. Journal of Business Ethics, 54(2), $103-119$.
Baden, D. A., Harwood, I. A., \& Woodward, D. G. (2009). The effect of buyer pressure on suppliers in SMEs to demonstrate CSR practices: An added incentive or counter productive? European Management Journal, 27(6), 429-441. doi:10.1016/j.emj.2008.10.004

Barth, F. (1993). Are values real? The enigma of naturalism in the anthropological imputation of values. In M. Hechter, L. Nadel, \& R. E. Michod (Eds.). The origin of values (pp. 31-46). New York: Aldine de Gruyter.

Betz, N. E., Fitzgerald, L. F., \& Hill, R. E. (1989). Trait-factor theories: Traditional cornerstone of career theory. Handbook of career theory, 26-40.

Bigne-Alcaniz, E., \& Curras-Perez, R. (2008). Does corporate social responsibility image influence on purchase intent? The role of consumer company identification. Universia Business Review. Retrieved from https://ubr.universia.net/

Bowd, R., Bowd, L., \& Harris, P. (2006). Communicating corporate social responsibility: An exploratory case study of a major UK retail centre. Journal of Public Affairs, 6(2), 147-155. doi:10.1002/pa.220

Buil, I., Melero, I., \& Montaner, T. (2012). Cause-related marketing strategy: Success factors. Universia Business Review. Retrived from https://ubr.universia.net/

Calero, J. (2003). La educación superior en España: Financiación y acceso. Revista de Educación, (330), 205-215.

Choi, D. Y., \& Gray, E. R. (2008). Socially responsible entrepreneurs: What do they do to create and build their companies? Business Horizons, 51(4), 341-352. doi:10.1016/j.bushor.2008.02.010

Coate, C., \& Frey, K. (2000). Some evidence on the ethical disposition of accounting students: Context and gender implications. Teaching Business Ethics, 4(4), 379-404. doi:10.1023/a:1009827807550

Dahlsrud, A. (2008). How corporate social responsibility is defined: An analysis of 37 definitions. Corporate Social Responsibility and Environmental Management, 15(1), 1-13. doi:10.1002/csr.132

Egri, C. P., \& Ralston, D. A. (2004). Generation cohorts and personal values: A comparison of China and the United States. Organization Science, 15(2), 210-220.

Feather, N. T. (1996). Values, deservingness, and attitudes toward high achievers: Research on tall poppies. In C. Seligman, J. M. Olson, \& M. P. Zanna (Eds.), The psychology of values: The Ontario symposium (Vol. 8, pp. 215-251). Mahwah, New Jersey: Lawrence Erlbaum Associates.

Fernando, M. (2010). Corporate social responsibility in the wake of the Asian tsunami: Effect of time on the genuineness of CSR initiatives. European Management Journal, 28(1), 68-79. doi:10.1016/j. emj.2009.08.002

Fernando, M., \& Almeida, S. (2012). The organizational virtuousness of strategic corporate social responsibility: A case of the Sri Lankan family-owned enterprise MAS Holdings. European Management Journal, 30(6), 564-576. doi:10.1016/j.emj.2012.08.003

Fernando, M., \& Sim, A. B. (2011). Strategic ambiguity and leaders' responsibility beyond maximizing profits. European Management Journal, 29(6), 504-513. doi:10.1016/j.emj.2011.08.001

Forsyth, D. R. (1980). A taxonomy of ethical ideologies. Journal of Personality and Social Psychology, 39(1), 175-184. doi:10.1037/00223514.39.1.175

Frazer, M. J., \& Kornhauser, A. (1988). Ethics and social responsibility in science education. British Journal of Educational Studies, 36(1), 76-77. 
Gil-Pechuan, I., Expósito-Langa, M., \& Tomas-Miquel, J. V. (2013) International entrepreneurship in SMEs: A study of influencing factors in the textile industry. International Entrepreneurship and Management Journal, 9(1), 45-57. doi:10.1007/s11365-012-0242-3

Gladwell, M. (2000). The tipping point: How little things can make a big difference. Boston: Little, Brown \& Company.

Gisbert Grifo, M. (2007). Mujer y sociedad: Evolución de la mujer en la sociedad y en el mundo laboral en el Siglo XX. Realidad actual de la mujer en España. Valencia: Santander.

Harwood, I., Humby, S., \& Harwood, A. (2011). On the resilience of corporate social responsibility. European Management Journal, 29(4), 283-290. doi:10.1016/j.emj.2011.04.001

Hemingway, C. A., \& MacLagan, P. W. (2004). Managers' personal values as drivers of corporate social responsibility. Journal of Business Ethics, 50(1), 33-44. doi:10.1023/b:busi.0000020964.80208.c9

Hofstede, G. (1980). Culture's consequences: International differences in work-related Values. Beverly Hills, CA: Sage.

Ibrahim, N. A., Angelidis, J. P., \& Howard, D. P. (2006). Corporate social responsibility: A comparative analysis of perceptions of practicing accountants and accounting students. Journal Business Ethics, 66(23), 157-167. doi:10.1007/s10551-005-5572-4

Koivula, N. (2008). Basic human values in the workplace. Social Psychological Studies, 17, 1-141.

Kristiansen, C. M., \& Hotte, A. M. (1996). Morality and the self: Implications for the when and how a value-attitude-behavior relations. In C. Seligman, J. M. Olson, \& M. P. Zanna (Eds.). The psychology of values: The Ontario symposium (Vol. 8, pp. 77-105). Mahwah, New Jersey: Lawrence Erlbaum Associates.

Lan, G., Gowing, M., McManhon, S., Rieger, F., \& King, N. (2008). A study of the relationship between personal values and moral reasoning of undergraduate business students. Journal of Business Ethics, 78(1), 121-139. doi:10.1007/s10551-006-9322-z

Longenecker, J., McKinney, J., \& Moore, C. (1989). The generation gap in business ethics. Business Horizons, 32(5), 9-14. doi:10.1016/00076813(89)90076-1

Macalister, T. (2008). A change in the climate: Credit crunch makes the bottom line the top issue. The Guardian. Retrieved from http:// www.theguardian.com/business $/ 2008 / \mathrm{mar} / 06 /$ greenbusiness. creditcrunch.

Norman,W., \& MacDonald, C. (2004). Getting to the bottom of triple bottom line. Business Ethics Quarterly. 14(2), 243-262.

Olver, J. M., \& Mooradian, T. A. (2003). Personality traits and personal values: A conceptual and empirical integration. Personality and Individual Differences, 35(1), 109-125. doi:10.1016/S01918869(02)00145-9

Pelsmacker, P. D., Janssens, E., Sterckx, \& Mielants, C. (2006). Fairtrade beliefs, attitudes and buying behaviour of Belgian consumers. International Journal of Nonprofit and Voluntary Sector Marketing, 11(2), 125-138. doi:10.1002/nvsm.47

Perez-Ruiz, A., \& Rodríguez del Bosque, I. (2012). Corporate social responsibility image in a financial crisis context: The case of the Spanish financial industry. Universia Business Review. Retrieved from https://ubr.universia.net/

Perrinjaquet, A., Furrer, O., Usunier, J.-C., Cestre, G., \& Valette-Florence, P. (2007). A test of the quasi-circumplex structure of human values. Journal of Research in Personality, 41(4), 820-840. doi:10.1016/j. jrp.2006.10.006
Pomering, A., \& Johnson, L. W. (2009). Advertising corporate social responsibility initiatives to communicate corporate image: Inhibiting scepticism to enhance persuasion. Corporate Communications: An Internal Journal, 14(4), 420-439. doi:10.1108/13563280910998763

Rama, D. V., Ravenscroft, S. P., Wolcott, S. K., \& Zlotkowski, E. (2000). Service-learning outcomes: Guidelines for educators and researchers. Issues in Accounting Education, 15(4), 657-692. doi:10.2308/ iace.2000.15.4.657

Rokeach, M. (1979). Understanding human values. New York: Free Press.

Rugger, D., \& King, E.W. (1992). A study of the effect of age and gender upon student business ethics. Journal Business Ethics, 11(3), 179186. doi:10.1007/bfoo 871965

Ruivo, P., Oliveira, T., \& Neto, M. (2012). ERP use and value: Portuguese and Spanish SMEs. Industrial Management \& Data Systems, 112(7), 1008-1025. doi:10.1108/02635571211254998

Schmeltz, L. (2012). Consumer-orientated CSR communication: Focusing on ability or morality? Corporate Communications: An International Journal, 17(1), 29-49.

Schwartz, S. H. (1992). Universals in the content and structure of values: Theoretical advances and empirical tests in 20 countries. In M. P. Zonna (Ed.), Advances in experimental social psychology (pp. 1-66). San Diego, CA: Academic Press.

Schwartz, S. H. (1994). Are there universal aspects in the structure and contents of human values? Journal of Social Issues, 50(4), 19-45. doi:10.1111/j.1540-4560.1994.tbo1196.x

Schwartz, S. H. (1996). Value priorities and behavior: Applying a theory of integrated value systems. In C. Seligman, J. M. Olson, \& M. P. Zanna (Ed.), The psychology of values: The Ontario symposium (Vol. 8, pp. 1-24). Hillsdale, NJ: Erlbaum.

Schwartz, S. H. (1999). A theory of cultural values and some implications for work. Applied Psychology: An International Review, 48(1), 23-47. doi:10.1111/j.1464-0597.1999.tboo047.x

Schwartz, S. H. (2005a). Robustness and fruitfulness of a theory of universals in individual human values. In A. Tamayo, \& J. Porto (Eds.), Valores e comportamento nas organizações (Values and behavior in organisations) (pp. 56-95). Petropolis, Brazil: Vozes.

Schwartz, S. H. (2005b). Basic human values: Their content and structure across countries. In A. Tamayo, \& J. B. Porto (Eds.), Valores e comportamento nas organizações (pp. 21-55). Petrópolis, Brazil: Vozes.

Schwartz, S. H. (2006). Value orientations: Measurement, antecedents and consequences across nations. In R. Jowell, C. Roberts, R. Fitzgerald, \& G. Eva (Eds.), Measuring attitudes cross nationally lessons from the European Social Survey. London: Sage.

Schwartz, S. H., \& Bardi, A. (1997). Influences of adaptation to communist rule on value priorities in Eastern Europe. Political Psychology, 18(2), 385-410. doi:10.1111/0162-895x.00062

Schwartz, S. H., \& Bardi, A. (2001). Value hierarchies across cultures: Taking a similarities perspective. Journal of Cross-Cultural Psychology, 32(3), 268-290. doi:10.1177/0022022101032003002

Schwartz, S. H., \& Sagiv, L. (1995). Identifying culture-specifics in the content and structure of values. Journal of Cross-Cultural Psychology, 26(1), 92-116. doi:10.1177/0022022195261007

Schwartz, S. H., Melech, G., Lehmann, A., Burgess, S., Harris, M., \& Owens, V. (2001). Extending the cross-cultural validity of the theory of basic human values with a different method of measurement. Journal of Cross-Cultural Psychology, 32(5), 519-542. doi:10.1177/0022022101032005001 
Siltaoja, M. E. (2006). Value priorities as combining core factors between CSR and reputation: A qualitative study. Journal of Business Ethics, 68(1), 91-111. doi:10.1007/s10551-006-9042-4

Smith, P. B. (2004). Nations, cultures, and individuals new perspectives and old dilemmas. Journal of Cross-Cultural Psychology, 35(1), 6-12. doi:10.1177/0022022103260460

Smith, N. C., \& Williams, E. (2011). Responsible consumers and stakeholder marketing: Building a virtuous circle of social responsibility. Universia Business Review. Retrieved from https:// ubr.universia.net/

Sobczak, A., Debucquet, G., \& Havard, C. (2006). The impact of higher education on students' and young managers' perception of companies and CSR: An exploratory analysis. Corporate Governance: The International Journal of Business in Society, 6(4), 463-474. doi:10.1108/14720700610689577

Sprinkle, G. B., \& Mainess, L. A. (2010). The benefits and cost of corporate social responsibility. Business Horizons, 53(5), 445-453. doi:10.1016/j.bushor.2010.05.006

Steenkamp, J.-B. E. M., Hofstede, F., \& Wedel, M. (1999). A cross-national investigation into the individual and national cultural antecedents of consumer innovativeness. Journal of Marketing, 63(2), 55-69.

Stevens, G. (1984). Ethical inclinations of tomorrow's citizens: Actions speak louder? Journal of Business Education, 59, 147-152.

Thøgersen, J., \& Ölander, F. (2002). Human values and the emergence of a sustainable consumption pattern: A panel study. Journal of Economic Psychology, 23(5), 605-630. doi:10.1016/S0167-4870(02)00120-4
Wang, L., \& Juslin, H. (2011). The effects of value on the perception of corporate social responsibility implementation: A study of Chinese youth. Corporate Social Responsibility and Environmental Management, 18(4), 246-262. doi:10.1002/csr.250

Wang, L., \& Juslin, H. (2012). Values and corporate social responsibility perceptions of Chinese university students. Journal of Academic Ethics, 10(1), 57-82. doi:10.1007/S10805-012-9148-5

Weber, J., \& Glyptis, S. M. (2000). Measuring the impact of a business ethics course and community service experience on students' values and opinions. Teaching Business Ethics, 4(4), 341-358. doi:10.1023/a:1009862806641

Weber, P. S., Weber, J. E., Sleeper, B. J., \& Schneider, K. C. (2004). Selfefficacy toward service, civic participation and the business student: Scale development and validation. Journal of Business Ethics, 49(4), 359-369. doi:10.1023/b:busi.0000020881.58352.ab

Wilson, M. S. (2005). A social-value analysis of postmaterialism. Journal of Social Psychology, 145(2), 209-224. doi:10.3200/socp.145.2.209-224

Willman, J. (2008), Stormy times ahead for responsibility agenda, The Financial Times. Retrieved from http://www.ft.com/cms/s/o/ 807fa3aa-4a47-11dd-891a-000077b07658,dwp_uuid=e1440094270d-11dd-b7cb-000077b07658.html?nclick_check=1

Wong, A., Long, F., \& Elankumaran, S. (2010). Business students' perception of corporate social responsibility: The United States, China, and India. Corporate Social Responsibility and Environmental Management, 17(5), 299-310. doi:10.1002/csr.216

Yao, G., Cheng, Y. P.., \& Cheng, C. P. (2009). The quality of life in Taiwan. Social Indicators Research, 92(2), 377-404. doi:10.1007/S11205008-9353-1 